\title{
Racial incidence of carcinoma of the bronchus in Malaya
}

\author{
M. R. J. SNELLING AND CHOOI MUN KAM \\ From the Lady Templer Hospital, Kuala Lumpur, Malaysia
}

Malaya has a multiracial population of approximately eight million composed of $50 \%$ Malay, $37 \%$ Chinese, $11 \cdot 2 \%$ Indian, and $1.8 \%$ others. In addition, there are 43,000 aborigines who live mainly in the jungle. Climatically, Malaya is a tropical country with a temperature varying between $70^{\circ}$ and $90^{\circ} \mathrm{F}$. all the year round. There is no atmospheric pollution as yet from industry, and smog does not occur. Diesel vehicles for transportation are common.

The following is an account of 142 cases of histologically proven bronchial carcinoma which occurred in one hospital in Malaya from 1 July 1958 to 31 December 1965-that is, over a period of seven and a half years. During this time, 5,200 patients with thoracic disease were admitted to the hospital. Of these, approximately $15 \%$ were Malay, $54 \%$ Chinese, $13 \%$ Indians, and 18\% others (Eurasian, European, and aborigine).

Table I shows that of the 142 cases 109 were males and 33 females, giving a ratio of 3.3 males to 1 female. The usual reported ratio is higher (Cohen and Hossain, 1966). Of the males 84.4\% and of the females $97 \%$ were Chinese. Carcinoma of the bronchus, however, does occur in all races.

T A B L E I

CASES OF BRONCHIAL CARCINOMA, BY RACE AND SEX

\begin{tabular}{|c|c|c|c|c|}
\hline \multirow{2}{*}{\multicolumn{2}{|c|}{ Race }} & \multicolumn{2}{|c|}{ No. of Cases } & \multirow{2}{*}{ Percentage } \\
\hline & & Male & Female & \\
\hline $\begin{array}{ll}\text { Malay } & \ldots \\
\text { Chinese } & \ldots \\
\text { Indian } & \ldots \\
\text { Others } & \ldots\end{array}$ & $\begin{array}{l}\ldots \\
\cdots \\
\cdots\end{array}$ & $\begin{array}{r}5 \\
92 \\
6 \\
6\end{array}$ & $\begin{array}{r}0 \\
32 \\
0 \\
1\end{array}$ & $\begin{array}{r}3 \cdot 5 \\
87 \cdot 3 \\
4 \cdot 2 \\
5 \cdot 0\end{array}$ \\
\hline Total & .. & 109 & 33 & \\
\hline
\end{tabular}

Table II shows that the majority of cases occurred in patients between the ages of 41 and 60 years, that 13 patients $(9 \cdot 1 \%)$ were under 40 and two patients were aged 40 years. Of the 142 patients, 73 had the lesion on the right side, 68 on the left side, and in one female the lesion was bilateral.

The figures given for 'malignant cells' could not 을 be further classified as the amount of tissue submitted for histology was insufficient, but malignant cells were definitely present.

T A B L E I I

CASES OF BRONCHIAL CARCINOMA ACCORDING TO AGE GROUP

\begin{tabular}{c|c}
\hline Age & No. of Cases \\
\hline $21-$ & 4 \\
$31-$ & 11 (incl. 2 aged 40 yrs) \\
$41-$ & 57 \\
$51-$ & 54 \\
$60+$ & 26 \\
\hline
\end{tabular}

\begin{tabular}{|c|c|c|c|c|c|}
\hline \multirow{3}{*}{ Type } & \multicolumn{4}{|c|}{ No. of Cases } & \multirow{3}{*}{$\underset{\%}{\text { Overall }}$} \\
\hline & \multicolumn{2}{|c|}{ Male } & \multicolumn{2}{|c|}{ Female } & \\
\hline & No. & $\%$ & No. & $\%$ & \\
\hline $\begin{array}{l}\text { Adenocarcinoma } \\
\text { Squamous cell }\end{array}$.. & $\begin{array}{r}2 \\
76 \\
2 \\
6 \\
14 \\
7 \\
2\end{array}$ & $\begin{array}{r}1.8 \\
69.7 \\
1.8 \\
5.5 \\
12.8 \\
6.4 \\
1.8\end{array}$ & $\begin{array}{l}8 \\
9 \\
0 \\
2 \\
8 \\
5 \\
1\end{array}$ & $\begin{array}{r}24 \cdot 2 \\
27 \cdot 3 \\
0 \\
6 \cdot 0 \\
24 \cdot 2 \\
15 \cdot 2 \\
3 \cdot 0\end{array}$ & $\begin{array}{r}7 \cdot 0 \\
59 \cdot 8 \\
1 \cdot 4 \\
5 \cdot 6 \\
15 \cdot 5 \\
8 \cdot 6 \\
2 \cdot 1\end{array}$ \\
\hline Total & 109 & & 33 & & \\
\hline
\end{tabular}

Table III shows that squamous-cell carcinoma o is the most common tumour in this series-i.e., $N$ $59 \cdot 8 \%$ of the total carcinoma cases. This agrees with the findings in other reports (Taylor, Shinton, and Waterhouse, 1963).

Table IV shows that $39.4 \%$ of the cases were diagnosed by bronchoscopy. This is a finding similar to that of Taylor et al. (1963), whose figure was $37 \%$, and to that of Nissenbaum (1964). The fact that $35 \cdot 2 \%$ of cases were diagnosed at thoracotomy shows that radiology is still a common method for diagnosing carcinoma of the bronchus. 
T A B LE I V

METHOD OF DIAGNOSIS

\begin{tabular}{|c|c|c|}
\hline & \multicolumn{2}{|c|}{ Cases } \\
\hline & No. & $\%$ \\
\hline 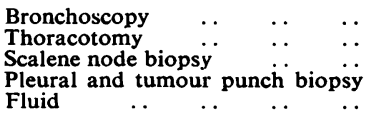 & $\begin{array}{r}56 \\
50 \\
19 \\
14 \\
3\end{array}$ & $\begin{array}{r}39 \cdot 4 \\
35 \cdot 2\end{array}$ \\
\hline
\end{tabular}

T A B L E V

\begin{tabular}{|c|c|c|c|c|c|c|c|c|}
\hline & \multicolumn{2}{|c|}{ Malay } & \multicolumn{2}{|c|}{ Chinese } & \multicolumn{2}{|c|}{ Indian } & \multicolumn{2}{|c|}{ Others } \\
\hline & No. & $\%$ & No. & $\%$ & No. & $\%$ & No. & $\%$ \\
\hline $\begin{array}{l}\text { No. of patients } \\
\text { admitted } \\
\text { No. of cases of } \\
\text { cancer of bron- } \\
\text { chus } \ldots \text {. } \\
\text { Incidence (\% of } \\
\text { cases admitted) }\end{array}$ & 790 & 0.6 & $\begin{array}{r}2,809 \\
124\end{array}$ & $54 \cdot 0$ & 655 & $13 \cdot 0$ & $\begin{array}{r}946 \\
7\end{array}$ & 18.0 \\
\hline
\end{tabular}

As has already been stated, during the period under review 5,200 patients were admitted to the hospital. From Table $\mathrm{V}$ it should be noted that over $4 \%$ of the Chinese patients were suffering from carcinoma of the bronchus.

\section{TREATMENT}

Of the 142 patients, 37 (26\%) underwent resection. This figure compares favourably with those published elsewhere. Unfortunately, as follow-up in this country is difficult or impossible, we are unable to state how these patients have progressed.

The incidence of pulmonary tuberculosis occurring together with carcinoma was $9 \cdot 8 \%$.

\section{DISCUSSION}

From the above Tables, one of the first things that will be noted in this small series is the high incidence of carcinoma of the bronchus among the Chinese. Fifty-four per cent. of all patients admitted to hospital were Chinese, and therefore one would expect to see more cases of carcinoma of the bronchus among them. But the percentage of Chinese in the total Malayan population is less than half-i.e., 37\%. From Table V it will be noted that $4.4 \%$ of all Chinese patients admitted suffered from carcinoma of the bronchus-exactly double that of all other races. It seems that this disease is more common to that race, as is nasopharyngeal carcinoma.

The other interesting aspect of racial incidence is that two patients in the series were aborigines, one male and one female. There are 43,000 aborigines in Malaya, about half of whom live in deep jungle and the other half on the perimeter in fairly close proximity to towns and villages. Those in the deep jungle can be reached only by helicopter, up rivers by boat, or by trekking. As part of the health programme, a camera unit and generators are flown in by helicopter, and the deepjungle dwellers as well as those on the perimeter have radiographs taken. So far 24,000 have now been radiographed, divided about equally between both categories. The authors of this paper have personally seen all the films in which any abnormality has been suspected after routine reading by the M.M.R. unit.

The Malayan aborigines have a life span of about 50 years. They are fairly heavy smokers and begin this practice at about 2 years of age. They smoke approximately $5 \mathrm{oz}$. tobacco per week, and the deep-jungle dwellers grow their own tobacco. The leaf is cured in the sun, wrapped in another leaf, and smoked in the rough form of a cigarette. Some samples of the cigarettes were analysed. It was found that the tobacco was not of a flue-cured type, the physical properties, the nicotine and sugar contents being typical of an indigenous air or sun-cured type. The nicotine contents of the smoke of the various types of 'rokok daun' (leaf cigarette) are variable, due in part to their physical make-up and the amounts of tobacco present. The tar contents of the smoke are high compared with ordinary paper-wrapped, flue-cured, air-cured or mixed flue-cured and air-cured cigarettes. Just what proportion of the total smoke tar is attributable to the wrapper leaves rather than to the tobacco is not known but it is probably appreciable.

The other aborigines, living on the perimeter, smoke as heavily but prefer the 'Western' type of cigarette. In spite of approximately 48 years of fairly heavy smoking, only two cases of bronchial carcinoma have been found among the 24,000 who had radiographs taken. Both of these were aborigines living on the perimeter of the jungle.

Many patients with suspicious films have been investigated by bronchoscopy and scalene node biopsy. Carcinoma does occur in the Malayan aborigines in other sites, as in the other races.

In this series of 142 patients, $16.6 \%$ males and $78 \%$ females were non-smokers. Of the 85 who had proven squamous-cell carcinoma, $18.4 \%$ males and $66.6 \%$ females were non-smokers, giving an overall percentage of $23.5 \%$.

There was an incidence of $9 \cdot 1 \%$ carcinoma of the lung in people below the age of 40 years, which is higher than in the series reported by Kwong 
and Slade (1964), who found only 44 cases of carcinoma of the bronchus among patients less than 40 years of age out of 719 patients reviewed by them, giving an incidence of $6.1 \%$; it is also greater than that reported by Burford, Center, Ferguson, and Spjut (1958) and Galluzzi and Payne (1955). In the present series, there were 13 patients below the age of 40 , and among them eight patients-i.e., $61.5 \%$-had squamous-cell carcinoma.

Although this paper covers only a small series, we have seen, when visiting other hospitals in Malaya, many radiographs in which carcinoma of the bronchus has been suspected; but the patients refused further investigation, and we feel that this disease is not uncommon in this country.

\section{SUMMARY}

One hundred and forty-two cases of histologically proven carcinoma of the bronchus have been described.

The high incidence of this disease among the Chinese has been noted.

Smoking habits reveal that in this series there is a high incidence of non-smokers who had squamous-cell carcinoma, and that the incidence $\frac{\bar{D}}{\bar{D}}$ of carcinoma of the bronchus in aborigines in $\vec{\nabla}$ Malaya, who are fairly heavy smokers, is low.

The incidence of carcinoma of the bronchus in $\%$ patients below the age of 40 is high in comparison $\overrightarrow{0}$ with previous published reports.

We should like to thank Professor J. B. Duguid, C.B.E., and Dr. H. S. Ahlawalia, of the Institute of $\overrightarrow{\times}$ Medical Research, Kuala Lumpur, for the histologicalin reports, Dr. M. Bolton, M.B.E., Medical Officer to the $\overrightarrow{i r}$ Department of Aborigines, for his help and advice, and Mrs. B. Yap for secretarial help.

\section{REFERENCES}

Burford, T. H., Center, S., Ferguson, T. B., and Spjut, H. J. (1958) Results in the treatment of bronchogenic carcinoma. $J$. thorac. Surg., 36, 316.

Cohen, S., and Hossain, M. S. (1966). Primary carcinoma of the lung. Dis. Chest, 49, 67.

Galluzzi, S., and Payne, P. M. (1955). Bronchial carcinoma; $a^{\text {D }}$ statistical study of 741 necropsies with special reference to thedistribution of blood-borne metastases. Brit. J. Cancer, 9, 511 .

Kwong, K. H., and Slade, P. R. (1964). Carcinoma of the bronchus in young adults. Brit. J. Dis. Chest, 58, 124.

Nissenbaum, J. (1964). Bronchography in diagnosis of bronchogenic carcinoma. Dis. Chest, 46, 331.

Taylor, A. B., Shinton, N. K., and Waterhouse, J. A. H. (1963) Histology of bronchial carcinoma in relation to prognosis Thorax, 18, 178 